\title{
Cell Cycle Checkpoint/DNA Repair Antagonist IC83
}

National Cancer Institute

\section{Source}

National Cancer Institute. Cell Cycle Checkpoint/DNA Repair Antagonist IC83. NCI

Thesaurus. Code C67075.

A proprietary agent with potential antineoplastic activity. IC83 appears to targ et cell cycle checkpoint/DNA repair enzymes, which are involved in the recognition and repair of damaged DNA and are overexpressed in many types of cancer cells. Inhibition of cell cycle checkpoint/DNA repair enzymes may enhance the cytotoxicity of DNA damaging agents and dissipate tumor cell resistance to chemotherapy and radiation therapy. 